\title{
Reproductive biology of Parona signata (Actinopterygii: Carangidae), a valuable economic resource, in the coastal area of a Mar del Plata, Buenos Aires, Argentina
}

Correspondence: Mariano González-Castro gocastro@mdp.edu.ar

Submitted December 11, 2019 Accepted July 9, 2020 by Fernando Gibran Epub October 09, 2020

Online version ISSN 1982-0224 Print version ISSN 1679-6225

Neotrop. Ichthyol. vol. 18, no. 3, Maringá 2020

\section{${ }^{\oplus}$ Santiago Julián Bianchi ${ }^{1}$ and ${ }^{\oplus}$ Mariano González-Castro ${ }^{1,2}$}

The reproductive biology and life cycle of Parona leatherjacket, Parona signata, present in Mar del Plata $\left(38^{\circ} 00^{\prime} \mathrm{S} 57^{\circ} 33^{\prime} \mathrm{W}\right)$ coast, was studied. Samples were obtained monthly since January 2018 to February 2019 from the artisanal fishermen and the commercial fleet of Mar del Plata. A histological analysis was carried out and the main biologic-reproductive parameters were estimated: fecundity, oocyte frequency distribution and gonadosomatic index (GSI). Both the macroscopic and microscopic analyses showed reproductive activity in March and November. Mature females were recorded, which showed hydrated oocytes, as was evidenced by the histological procedures. Both, the histological and the oocyte diameter distribution analyses showed the presence of all oocyte maturation stages in ovaries in active-spawning subphase, indicating that P. signata is a multiple spawner with indeterminate annual fecundity. Batch fecundity ranged between 36,426 and 126,035 hydrated oocytes/ female. Relative fecundity ranged between 42 and 150 oocytes/g female ovary free.

Keywords: Fecundity, Gonad histology, Life cycle, Pampo solteiro, Reproductive ecology.

\footnotetext{
1 Laboratorio de Biotaxonomía Morfológica y Molecular de Peces (BIMOPE). Instituto de Investigaciones Marinas y Costeras, IIMyC-CONICET- UNMdP. Mar del Plata, Buenos Aires, Argentina. (SJB) santiagobianchi21@gmail.com.

2 Consejo Nacional de Investigaciones Científicas y Técnicas (CONICET). (MGC) gocastro@mdp.edu.ar (corresponding autor).
} 
Se estudió la biología reproductiva y el ciclo de vida de la palometa pintada, Parona signata en Mar del Plata ( $\left.38^{\circ} 00^{\prime} \mathrm{S} 57^{\circ} 33^{\circ} \mathrm{O}\right)$. Las muestras fueron obtenidas mensualmente desde enero de 2018, hasta febrero de 2019, provenientes de la pesca artesanal y/o de la flota comercial de la localidad Mar del Plata. Además, se llevó a cabo un análisis histológico y se estimaron los principales parámetros reproductivos tales como: la fecundidad, análisis de la distribución de la frecuencia de diámetros ovocitarios e índice gonadosomático (GSI) mensual. Tanto el análisis macroscópico como el microscópico permitieron afirmar que en los meses de marzo y noviembre existe actividad reproductiva. Se encontraron hembras en puesta, las cuales presentaron ovocitos hidratados en los cortes histológicos. Ambos, los análisis histológicos y de distribución de la frecuencia de diámetros oocitarios mostraron la presencia de todas las fases de maduración oocitaria en ovarios correspondientes a la sub-fase de desove activo, indicando que $P$. signata es un desovante parcial con fecundidad anual indeterminada. La fecundidad parcial osciló entre 36.426 y 126.035 oocitos hidratados/hembra. La fecundidad relativa varió entre 42 y 150 ovocitos por gramo de hembra libre de ovario.

Palabras clave: Ciclo de vida, Ecología reproductiva, Fecundidad, Histología gonadal, Palometa.

\section{INTRODUCTION}

The pelagic fishes are essential components in the marine ecosystem due to their important biomass in the intermediate levels of the trophic chain. They play an important role in the connection of the upper and lower trophic levels. This means lower level fishes serve as food for other species (Cury et al., 2003). Moreover, pelagic fishes include species of great commercial interest.

The argentine continental shelf bottoms possess a substrate composed mainly of sand, some mud and rocky areas. The waters that cover this region have a sub-Antarctic origin, diluted by continental discharges and modified by exchanges of mass and heat with the atmosphere. These nutrient rich sub-Antarctic currents and their interactions with continental discharges make the Atlantic coast of the province of Buenos Aires an important fish feeding and breeding area (Cousseau, Perrotta, 2013).

The Order Carangiformes (Actinopterygii) is a monophyletic fish group, widely distributed in the Atlantic, Pacific and Indian Oceans, which includes six families, 37 genera, and 160 species (Bannikov, 1987; Nelson et al., 2016). Only one family (Carangidae) occurs in Argentina and includes 140 species, which are extremely variable in body shape (Cousseau, 2010). Three species of this family are commercially important in the argentine sea: Parona signata (Jenyns, 1841), Trachurus lathami Nichols, 1920 and Seriola lalandi Valenciennes, 1833.

Parona signata (locally called as "Pampo-solteiro" or "Pampo-macho" (Brazil), "Palometa pintada" (Argentine) and "Parona leatherjacket" (global), is a medium size, coastal pelagic fish that occurs in South America, from Rio de Janeiro $\left(22^{\circ} 35^{\prime} \mathrm{S}\right)$ to the 
Estrecho de Magallanes and Islas Malvinas (Cousseau, Perrotta, 2013). Adult specimens of Parona leatherjacket can reach a maximum of $600 \mathrm{~mm}$ of total length, and the highest age recorded was 6 years old (San Román, 1976). Due to its commercial value and wide distribution, this species results an important economic resource for the region. It is commercialized in the domestic market, whole, fresh. It has been exported frozen whole (Cousseau, Perrotta, 2013). The landings statistics for Argentina ranged from 350 to 1123 tons (mean= 740 tons/year), between 2012 and 2016 (Navarro et al., 2019). Parona leatherjacket was recently evaluated by the IUCN and included in Red List of Threatened Species 2019 (Carpenter et al., 2019). As Carpenter et al. (2019) indicates: ... "This pelagic, nearshore species can be common and abundant in several parts of its range. It is commercially exploited in a large portion of its range (Argentina and Uruguay), and catch has declined by about $76 \%$ over the past decade. However, more information is needed on fishing effort trends over time before catch decline can be attributed to actual population decline. Given its broad overall range and the current lack of data to infer or suspect population decline, this species is listed as Least Concern. Research into fishing effort trends in Argentine and Uruguay should be a priority, moving forward".

Although the previous assessments point out that this resource must be a "hot spot" in research with conservation purposes, biology reproductive studies (including life cycle and estimates of reproductive parameters) of $P$. signata are scarce. At respect, an analysis of trends across studies of age and size at maturation support that fishing pressure is playing a major role in the life history changes observed in commercial fish stocks (Sharpe, Hendry, 2009). At present, the biological studies performed in P. signata include: age estimations and length-age relationships (San Román, 1976), ovarian development at macroscopic level (Macchi, Acha 1998), estimations of first maturity size (Perrotta et al., 2006). Finally, although a spring-summer spawning was suggested (Cousseau, Perrotta, 2013) no reliable histological data that support it, including epoch and area, was published at present. So far, no studies related to the life cycle (based on monthly samples during an annual cycle) of adults $P$. signata have been carried out. Moreover, neither estimation of monthly GSI means values nor fecundity has been previously reported for this species.

Taking into account the above-mentioned information, the aim of the present work was to study the life cycle of the Parona leatherjacket, P. signata, in Mar del Plata coast $\left(38^{\circ} 00^{\prime} \mathrm{S} 57^{\circ} 33^{\prime} \mathrm{W}\right)$, Buenos Aires, Argentine. The objectives were: (1) to perform an histological analysis of ovarian development during an annual cycle and describe the stages of oocyte development; (2) to characterize the seasons and spawning areas, if there were any in the area under study; (3) to estimate the main biologic reproductive parameters for the stock of $P$. signata that inhabits in Mar del Plata (batch fecundity, frequency of oocyte diameter distribution, and gonadosomatic index).

\section{MATERIAL AND METHODS}

Study area and fish sampling: Samples were collected monthly, from January 2018 to February 2019, from artisanal fishermen and the commercial fleet of Mar del Plata (3800'S 573' W), Buenos Aires province, Argentine. These fleets usually employed 
pelagic bottom-trawls with gates. A total of 111 females were collected and analyzed during the sampled period.

Additionally, temperature and salinity were retrieved from Servicio de Hidrografía Naval and then compared with the estimated biological parameters (http://www.hidro. gov.ar/ceado/Ef/EF_FIJAS.asp?op=8). Spawning epoch of fishes are usually defined by bounded ranges of these two environmental variables.

After collected, fishes were transported immediately to the Laboratorio de Biotaxonomía Morfológica y Molecular de Peces (BIMOPE), at Instituto de Investigaciones Marinas y Costeras (IIMyC) (UNMdP - CONICET). The specimens were taxonomically identified following Cousseau, Perrotta (2013). Total length (TL) and standard length (SL) were recorded to the nearest $\mathrm{mm}$. Total weight (TW) and ovary weight $(\mathrm{OW})$ were recorded to $0.1 \mathrm{~g}$ with an analytic balance. Specimens were sexed. A macroscopic and microscopic maturity scale was employed based on five phases according to Brown-Peterson et al. (2011), as follows: 1-inmature, 2-developing, 3-spawning capable (which include a sub-phase of active spawning), 4-regressing and 5-regenerating. Three voucher specimens were deposited in the Fish Collection of the IIMyC (UNMdP 5162, 5163 and 5164). Each individual was represented by a digital photograph and a tissue sample, stored in alcohol $96^{\circ}$.

Histological processing: Weighed ovaries were stored in Davidson solution for 12 hours. After that, ovaries were preserved in Ethanol $50^{\circ}$. A small tissue portion was removed from the fixed ovary and then it was histologically processed according to González-Castro et al. (2011) and López et al. (2013). Sections were cut at $5 \mu \mathrm{m}$ and stained with hematoxylin/eosin $(\mathrm{H} / \mathrm{E})$ technique.

Frequency distribution analysis of oocyte diameters: After the fixation, a small ovary portion was removed and rehydrated. A total of 220 oocytes per ovary were measured by the longest axis with a graduated ocular according to González-Castro et al. (2011). The oocyte diameter frequency distribution of six hydrated ovaries was plotted.

Fecundity estimation and Gonadosomatic Index (GSI): Batch fecundity (number of oocytes released per spawning) was estimated employing five ovaries in spawning capable maturation phase (active spawning sub-phase), stored in ethanol 50 after fixation. These ovaries contained hydrated oocytes and they showed no evidence of post-ovulatory follicles or atresic follicle. Three portions (of approximately $1 \mathrm{~g}$ ) of the anterior, medial and posterior parts of the gonad were rehydrated, weighed with an analytic balance $( \pm 0.0001 \mathrm{~g})$ and all hydrated oocytes were counted. Batch fecundity was calculated according to Hunter et al. (1985). Relative fecundity (number of hydrated oocytes per gram of ovary-free body weight) was calculated as the batch fecundity divided by female weight (ovary-free) (Hunter et al., 1985). The GSI was calculated as the ovary weight divided body weight (x 100). It was analyzed in relation of the annual cycle and maturity phases. In order to test homogeneity of variances (Homocedasticity) a Levene Test was performed. As this assumption was not met, a Welch ANOVA followed by the Games-Howell Post-Hoc Test $(\alpha=0.05)$ were performed, to test if exist differences in the females GSI among the sampled months. The Games-Howell PostHoc test is employed when equal variances are not assumed. 
Ovarian Cycle: From macroscopic and microscopic ovary analysis, the gonadal cycle was recognized.

\section{RESULTS}

Gonadosomatic index (GSI), sea temperature and salinity: Two peaks corresponding to March (GSI= $6.89 \pm 6.22 \mathrm{SD}$ ) and November (GSI=10.67 $\pm 2.64 \mathrm{SD}$ ) (where the maximum value was reached) were showed in the monthly average GSI values. These peaks corresponded to the reproductive period of P. signata. The GSI showed lower values in December $(1.76 \pm 0.6 \mathrm{SD})$. Moreover, the winter season is associated with small GSI values (Fig. 1). There were differences among groups, Welch ANOVA (F= 24.727, $\mathrm{p}<0.001$ ) and Games-Howell Post-Hoc test revealed that the GSI was higher for October (mean GSI = $6.20 \pm 2.51 \mathrm{SD}$ ) and November (mean GSI $=10.67 \pm 2.64 \mathrm{SD}$ ) when compared to the others months (data not shown), with the exception of March (mean GSI= $6.87 \pm 6.22 \mathrm{SD}$ ). There were no differences among the months of October, November and March (Oct-Nov p= 0.74; Mar-Oct p= 0.90; Mar-Nov p=1.00).

Sea temperature rounded $\sim 10^{\circ} \mathrm{C}$ in the winter season, while ranged between 17 to $21^{\circ} \mathrm{C}$ in the spring-summer season Highest values corresponded to the two GSI peaks in March and November $\left(20\right.$ and $17^{\circ} \mathrm{C}$, respectively). Accordingly, the lowest GSI mean value was obtained in August $(1.34 \pm 0.11 \mathrm{SD})$ and corresponded to the lower temperature mean values $\left(10^{\circ} \mathrm{C}\right)$. The salinity of 34 ups did not present fluctuations during the sample period.

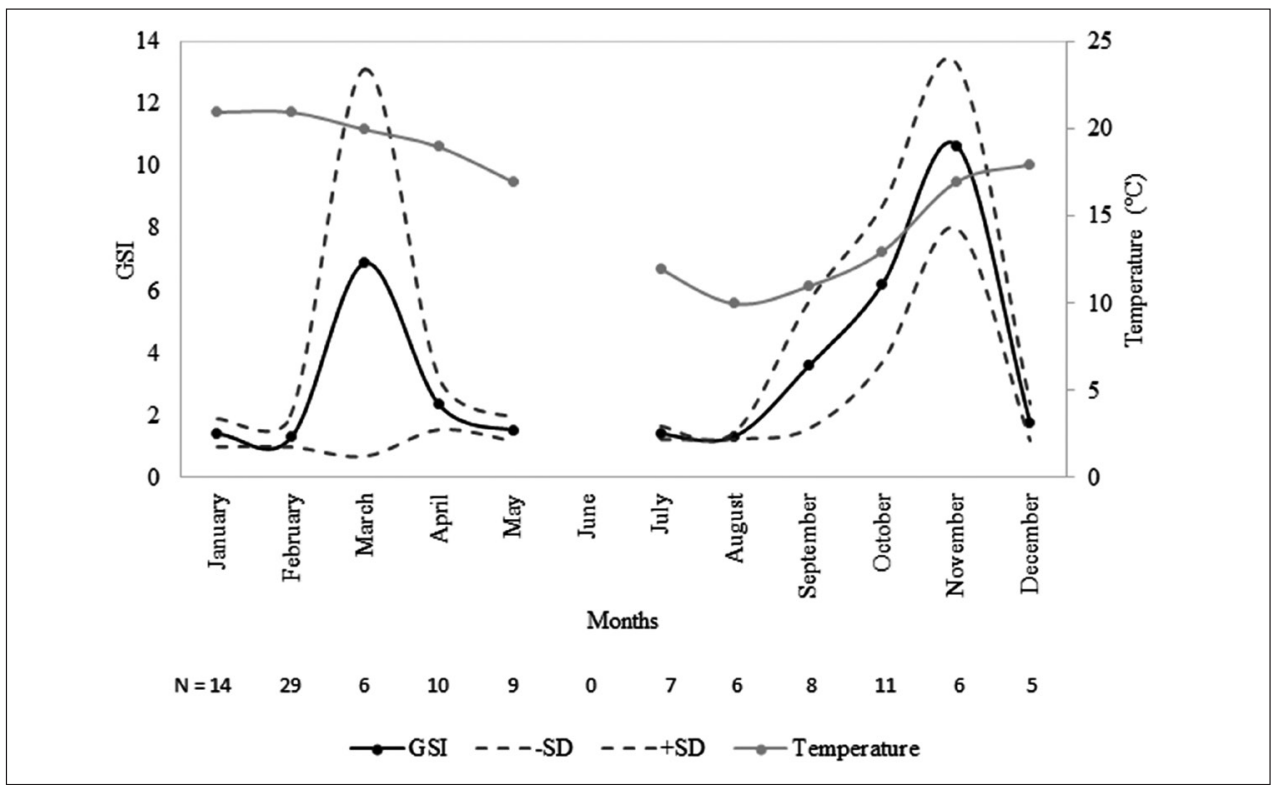

FIGURE 1 I Monthly variation of the gonadosomatic index (GSI) of females (black continuous line), standard deviation (dashed lines) and temperature (in Celsius degrees) (gray continuous line) based on an annual cycle. 
Ovarian cycle: Five ovarian phases were recorded. Phase 1 (immature individuals) $(\mathrm{n}=18)$ was recorded mostly between April, July and August. Phase 2 (development) $(n=35)$ and 3 (spawning capable) $(n=26)$ were recorded in almost every month, except for December. The most advanced maturity phase (active spawning sub-phase) was recorded in March and November. Phase 4 (regressing) ( $\mathrm{n}=15)$ was recorded in summer season and a few individuals in May. Finally, Phase 5 (regenerating) ( $\mathrm{n}=17)$ was recorded in February, April and May after the reproductive events (Fig. 2).

Microscopic description of the ovarian maturity phases: In the analyzed period, five phases were recorded:

1) Immature: in this phase individuals presented small pink ovaries, with a thin tunic. Ovaries contained only oogonias and oocytes in primary growth. Ovarian lamellas were arranged in order. This stage was observed between April and October.

2) Development: an increase in the ovarian size/weight characterized this phase. The oocytes and blood vessels become visible. The ovaries showed primary growth, cortical alveoli, and early vitelogenesis oocytes. This stage was observed in almost every month.

3) Spawning capable: the ovaries approximately occupied half of the abdominal cavity and they were yellow. Ovarian arteries and its ramifications were evident. The oocytes were macroscopically visible (mostly yolk oocytes). This stage was observed in all annual cycle months, without winter ones. In the active spawning sub-phase the ovaries occupied almost the total abdominal cavity and they were orange, with a thick tunic. Ovaries contained very big hydrated oocytes (approximately 1,250 $\mu \mathrm{m}$ ). This stage was observed in March and November.

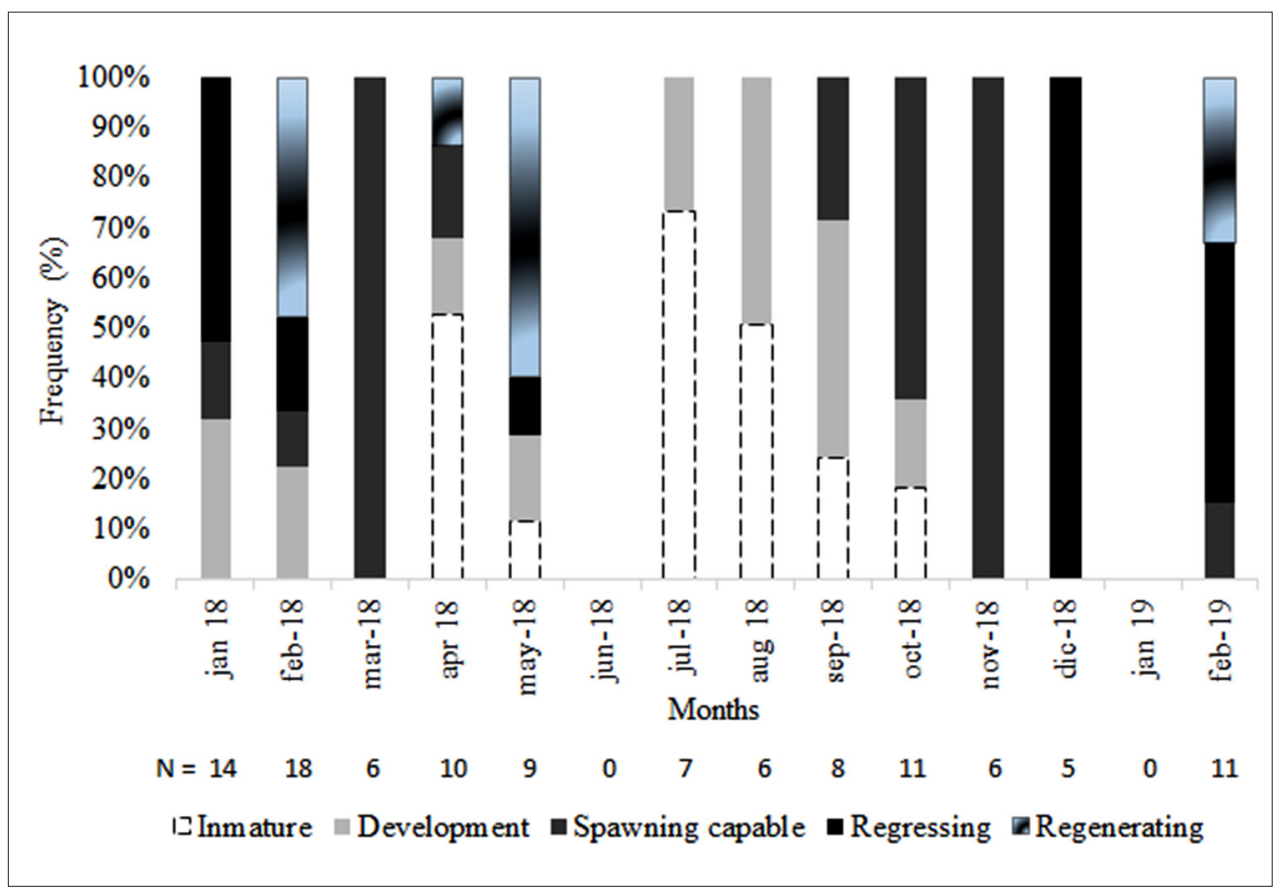

FIGURE 2 I Monthly relative frequency of the different gonadal development stages observed in females of Parona signata on the annual cycle. 
4) Regressing ovaries: this phase is characterized by flaccid ovaries with thick tunics, displaying prominent blood vessel due to recent spawning activity. Atresia and postovulatory follicles are typically present. This stage was observed in January, February, May and December.

5) Regenerating: the ovaries, in yellow, decreased their size. The tunic remained thick and the ovaries recovered the turgidity. Predominantly primary growth oocytes presented. This stage was observed in February, April and May.

Microscopic description of the development and growth of oocyte phases: During the analyzed period, the followings stages were observed: Primary growth oocytes; Cortical alveolus stage; Yolked oocytes; Hydrated oocytes; Atretic follicle; Post-ovulatory follicles (POFs) (Tab. 1, Fig. 3).

Frequency distribution of oocyte diameters. The size distribution of formalinpreserved oocytes (spawning capable phase) of P. signata is presented in the Fig. 4. The smallest group was composed mainly of primary growth oocytes (smaller than $150 \mu \mathrm{m}$ ). The second group was composed of cortical alveolus stage oocytes ranging from 200 to $300 \mu \mathrm{m}$. A third group included yolked oocytes between 350 and $750 \mu \mathrm{m}$. The fourth

TABLE 1 I Description of stages of oocyte development, atretic follicles and post-ovulatory follicles of Parona signata from the present study.

\begin{tabular}{|c|c|}
\hline Stages & Microscopic characteristics \\
\hline Primary growth oocytes & $\begin{array}{l}\text { Small cells with a diameter between } 50-200 \mu \mathrm{m} \text {, showing a big nucleus. } \\
\text { Between } 4-16 \text { nucleolus were found in their periphery (in some cases } \\
\text { rounding } 18 \text { nucleolus). These cells have a basophil cytoplasm. }\end{array}$ \\
\hline Cortical alveoli & $\begin{array}{l}\text { With a size between } 200-300 \mu \mathrm{m} \text {, with a big nucleus. Small vesicles, the } \\
\text { cortical alveoli, characterized this phase. They located in the cell periphery. } \\
\text { In this stage the cytoplasm is basophilic, the radiate zone is visible (highly } \\
\text { eosinophilic), as well as the follicular layer (granulosa and theca cells). }\end{array}$ \\
\hline Yolked oocytes & $\begin{array}{l}\text { Oocytes with diameters from } 350 \text { to } 750 \mu \mathrm{m} \text {. Yolk granules (with } \\
\text { eosinophilic affinity) present in the cytoplasm, due to the exogenous } \\
\text { vitellogenesis. Although less frequent, lipid vesicles are observed dispersed } \\
\text { between the yolk granules. Radiated zone (highly eosinophilic) and the } \\
\text { follicular cells reach their maximum development. The nucleus continues } \\
\text { in central position, with an irregular shape due to the cytoplasm growth. It } \\
\text { is remarkable the presence of lipid vessels in the yolked oocytes cytoplasm. }\end{array}$ \\
\hline Hydrated oocytes & $\begin{array}{l}\text { Hydrated oocytes; with a size between } 1000 \text { and } 1500 \mu \mathrm{m} \text {. Germinal vesicle } \\
\text { migration (GVM), and break down (GVBD) of nuclear membrane are } \\
\text { the previous steps to the cytoplasmic hydration, where the cellular size } \\
\text { increase notoriously. Hydrated oocytes displayed an irregular shape, due } \\
\text { to the alcohol dehydration performed during the histological procedures. }\end{array}$ \\
\hline Atretic follicles & $\begin{array}{l}\text { Disintegration and reabsorption of the oocytes by the follicular cells, from } \\
\text { the periphery to the center. Observed mainly at the end of the reproductive } \\
\text { cycle. Characterized by nucleus disintegration and autolysis of yolk } \\
\text { oocytes. }\end{array}$ \\
\hline Post-ovulatory follicles & $\begin{array}{l}\text { After ovulation, the remaining follicular cells form an irregular shape in } \\
\text { the ovary tissue. The follicular lumen size decreased and the degradation } \\
\text { increased according to the time since ovulation. Characterized by irregular } \\
\text { shape and advanced degradation. With a small follicular lumen. }\end{array}$ \\
\hline
\end{tabular}



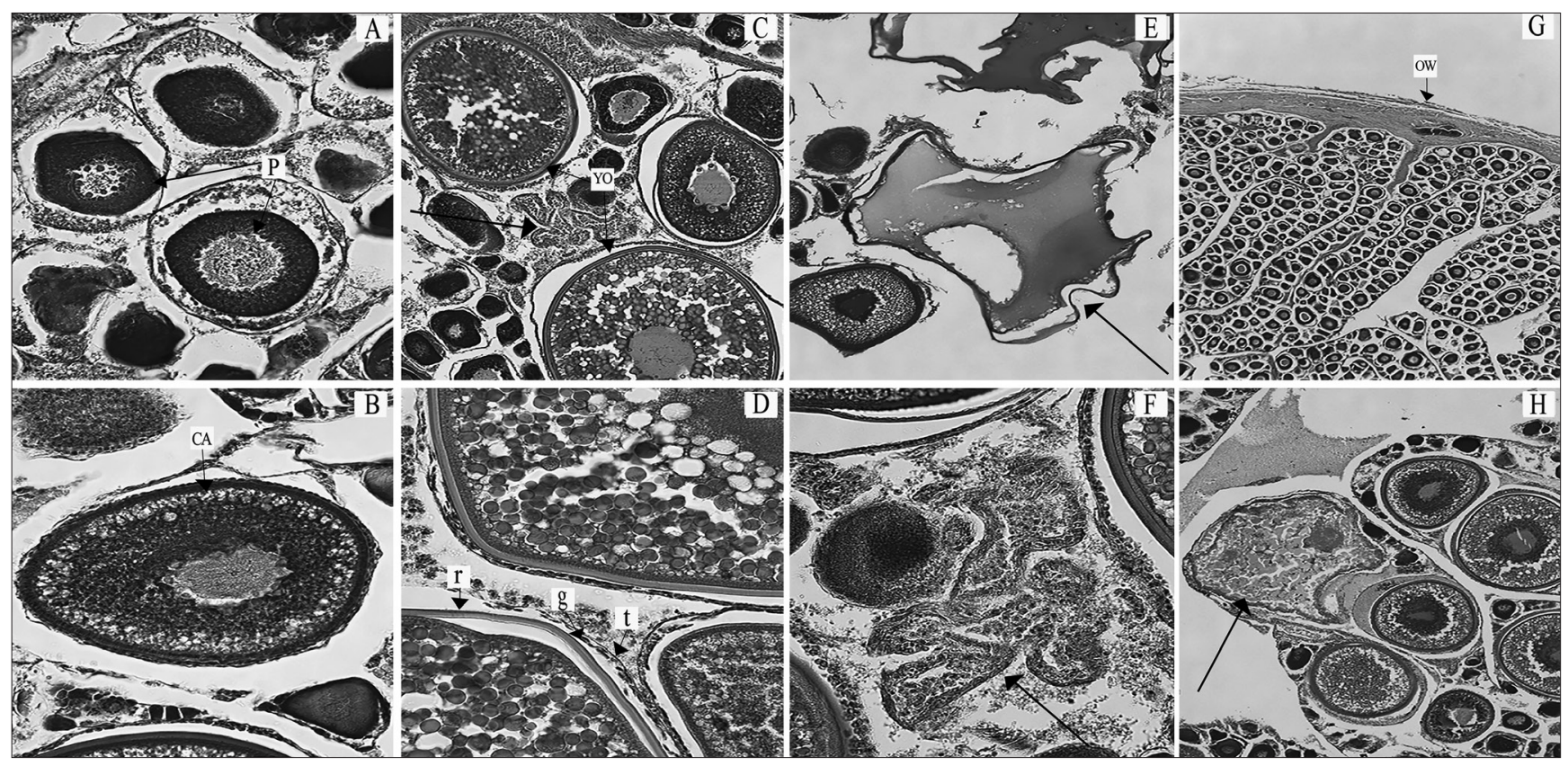

FIGURE 3 I Photomicrographs of Parona signata. A: primary growth oocytes (P); B: cortical alveoli oocytes (CA); C: yolked oocytes (YO) and a post-ovulatory follicle (large arrow); $\mathbf{D}$ : details of a yolked oocyte (r: radiate zone; g: granulosa cells; t: theca cells); E: hydrated oocyte (arrow); F: details of a post-ovulatory follicle (arrow); G: primary growth oocytes in an adult ovary (notice the thick wall of the ovary - OW); H: atresic follicle (arrow).

group included hydrated oocytes ranging from 800 to $1500 \mu \mathrm{m}$. Ovaries displayed a continuous distribution from primary growth to hydrated oocytes as revealed by the histological analysis. This indicates a constant recruitment of pre vitellogenic oocytes to the hydrated group during the reproductive season, which implies this species present an indeterminate fecundity.

Fecundity: Batch fecundity estimates ranged between 34,246 and 126,035 hydrated oocytes, with an average of $69,834( \pm 42,228)$. Batch fecundity estimated corresponding to females between 460 and $480 \mathrm{~mm}$ TL respectively. Relative fecundity estimates ranged between 42 and 150 oocytes per gram of female, for 490 and $460 \mathrm{~mm}$ TL, respectively.

\section{DISCUSSION}

This study constitutes the first contribution on the reproductive cycle of $P$. signata, based on a one-year complete monthly sampling, with a histological overview. The highest GSI values were obtained in November and March $(10.67 \pm 2.64$ SD and 6.89 $\pm 6.22 \mathrm{SD}$, respectively). During these months, the specimens were in spawning capable phase. Moreover, during this period females in the active spawning sub-phase were recorded. In December, a low GSI value $(1.76 \pm 0.6 \mathrm{SD})$ was observed, which was due to females in the regressing ovarian phase. Similar results were found in others carangid 


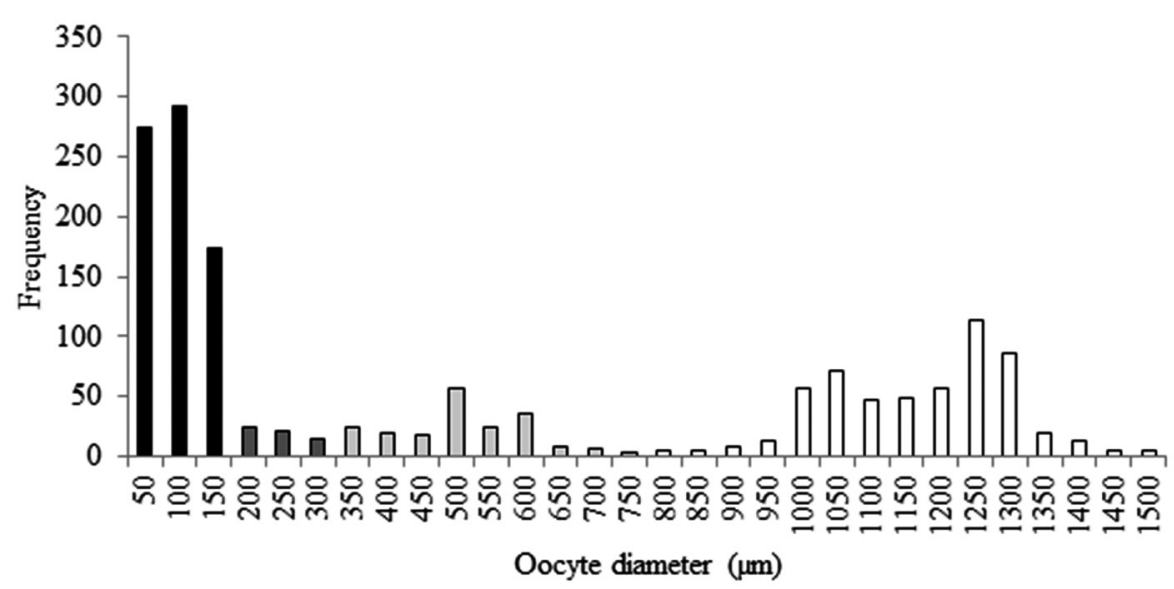

FIGURE 4 I Frequency distribution of oocyte diameters (n=3,000 oocytes measured of Parona signata). From black bars to white bars: primary growth oocyte, cortical alveoli, yolked oocytes and hydrated oocytes, respectively.

species, where the species showed two spawning peaks during its annual reproductive season. For example, Caranx ruber (Bloch, 1793), a native Cuban species exposed two spawning peaks in summer (Garcia-Arteaga, Reshetnikov, 1986). In addition, Scomberoides lysan (Fabricius, 1775) showed a reproductive activity during June and November (Thulasitha, Sivashanthini, 2013). However, other authors postulated that reproductive biology can be highly variable between carangids (McBride et al., 2002).

During the studied period, P. signata was present in all months, except on June 2018, when no records were obtained. This could imply that P. signata would make an offshore migration, where the temperature would be warmer than in the coast. Another explanation would be to understand it (no P. signata catches on June) as a fortuity event derived from the sampling logistic. Radonic (1997) reported the presence of P. signata from January to June in Mar del Plata's shores. In the same way, Lagos (2001) recorded this species in Cabo San Antonio's (Buenos Aires Province, Argentina) shores during all year long. Our results indicated that the reproductive events of $P$. signata were performed at temperatures between 21 and $17^{\circ} \mathrm{C}$ (March and November, respectively), and salinity was $\sim 34$ ups. These agree with Lagos (2001), which reported gravid females in Cabo San Antonio shores (36 17’35" S 56 46’37” W) during the spring-summer season. Moreover, Acha (2012) recorded eggs and larvae with densities between 0.01 and 10 larvae $/ \mathrm{m}^{3}$ in the surface of El Rincón (Buenos Aires Province, Argentina), during November 2008. Finally, Perrotta et al. (2006) and González-Castro et al. (2009) recorded the presence of immatures specimens of P. signata during the autumn-winter season in estuary areas. These results suggest that $P$. signata could be using some estuaries of Buenos Aires Province with feeding/growing purposes.

The histological analysis and the oocyte diameter frequency distribution showed the presence of all oocyte maturation stages in ovaries in the active-spawning subphase, according to Brown-Peterson et al. (2011). This fact indicates that $P$. signata is a multiple spawner with indeterminate annual fecundity. This species displayed continuous oocyte 
recruitment throughout the reproductive season (November, March). The oocyte diameter frequent distribution of $P$. signata evidenced four clutches/ groups of oocytes easily differentiable in histological slides (between 50 and $1500 \mu \mathrm{m}$ ) and ovaries displayed a continuous distribution from primary growth to advanced yolked oocytes. These four clutches showed a continuous distribution and were composed of oocytes in primary growth, cortical alveolus stage, yolked oocytes and finally the hydrated oocytes. It was remarkable the presence of lipid vessels in the yolked oocytes cytoplasm. They would form an oil droplet in the hydrated oocytes, which is vital for the eggs' buoyancy and larvae survival and development.

In this study, hydrated oocytes were employed for the fecundity estimation. The batch fecundity showed a range between 36,426 to 126,035 oocytes/ female (with an average of $69,834 \pm 42,228 \mathrm{SD}$ oocytes), corresponding to gravid females with a ranged length between 460 to $540 \mathrm{~mm}$ (TL). This estimation of fecundity was higher when compared with those of the most important species with similar reproductive strategies. For example, the batch fecundity of Anchoa marinii Hildebrand, 1943 ranged from 749 to 3,207, for individuals of 76-114mm TL (López et al., 2013). Rodrigues et al. (2008) reported batch fecundity estimation of 13,675 oocytes $( \pm 856)$ for Engraulis anchoita Hubbs, Marini, 1935. On the other hand, when comparing the relative fecundity of $P$. signata with the other mentioned species, the values estimated in the present work were much lower. They ranged from 42-150 hydrated oocytes/ female gram (free ovary), compared with 127-422 oocytes for A. marinii (López et al., 2013); and 574 oocytes for E. anchoita (Pájaro et al., 1997). These differences could be due to the largest size of the hydrated oocytes of $P$. signata (800 to $1500 \mu \mathrm{m}$ ), in comparison with other local species

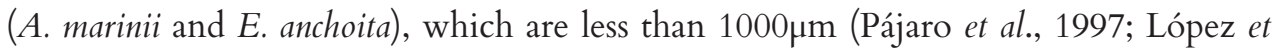
al., 2013). The size and number of eggs produced vary greatly among species and all of these traits have important consequences for survival. Egg is positively correlated with the duration of the incubation period and the size of the larva. The greater amount of yolk in large eggs provides more total energy for growth, resulting in larger larvae at hatching and at first feeding. This yields several vital benefits: (a) larvae emerge with a better fitness of behavioral and physiological capabilities than less developed larvae from smaller eggs; (b) they are more resistant to starvation because weight-specific metabolic rates are lower and bodily energy stores are greater; and (c) the larval period is shorter (Fuiman, 2002).

It is necessary to take care of this important economic resource, mainly because is an endemic South West Atlantic Ocean species, but also represent a valuable protein source. An exploited stock is renewed by means of recruitment through reproduction. If fishing pressure on this resource doesn't have any management measure, its populations could be seriously threatened by mature losses. One way of mitigating this risk is to ensure that minimal fishing pressure applied to the populations before the fish reach maturity. So, given that $P$. signata reach maturity at $30.5 \mathrm{~cm}$ these fish should not be caught until getting such size. Moreover, as the spawning peaks were recorded in March and November, the gravid females of $P$. signata should be protected from fishing pressure during this period, in order to maintain a sustainable fishery and a proper intraspecific genetic variability. A seasonal closure would be a convenient measure, in order to protect the key life stages of this species. Following these steps, P. signata longterm viability might be safe. 
This is the first integrative approach of the reproductive biology of $P$. signata, an important food resource for Argentine, Uruguay and Brazil. Our results exposed above strongly suggest that $P$. signata reproduce in the Mar del Plata coastal zone, and the adult specimens would occur during all year long. Future studies should be focused to obtain more specimens in the nearest areas to determine if there exists any correlation with the spawning season and to corroborate the fecundity estimates. Moreover, it will be necessary to expand the sampling area, to infer the plausible movements of this species and hypothesize a life-history model.

\section{ACKNOWLEDGMENTS}

The authors would like to thank Graciela Isabel Álvarez (CONICET) for histological support; Pedro A. Olmos, Diego Rodriguez and Pablo Rizzo for helping in the specimens collect. This work was partially supported by a grant from Consejo Nacional de Investigaciones Científicas y Tecnológicas (CONICET), Argentina (PIP Nº 0339).

\section{REFERENCES}

- Acha EM, Orduna M, Rodrigues KA, Militelli MI, Braverman MS. Caracterización de la zona de 'El Rincón' (provincia de Buenos Aires) como área de reproducción de peces costeros. Rev Invest Desarr Pesq. 2012; (21):31-41.

- Bannikov AF. On the taxonomy, composition and origin of the family Carangidae. J Ichthyol. 1987; 27:1-8.

- Brown-Peterson NJ, Wyanski DM, Saborido-Rey F, Macewicz BJ, LowerreBarbieri SK. A standardized terminology for describing reproductive development in fishes. Mar Coast Fish. 2011; 3(1):52-70. https://doi.org/10.1080/19425120.2011.555724

- Carpenter KE, Borsa P, Obota C. Parona signata. The IUCN Red List of Threatened Species. 2019; e.T195049A115606278. http://dx.doi.org/10.2305/IUCN.UK.2019-2. RLTS.T195049A115606278.en

- Cousseau MB. Ictiología: Aspectos fundamentales: La vida de los peces sudamericanos. Mar del Plata: Editorial de la Universidad Nacional de Mar del Plata; 2010.

- Cousseau MB, Perrotta RG. Peces marinos de Argentina: biología, distribución, pesca. Mar del Plata: INIDEP; 2013.
- Cury P, Shannon LJ, Shin YJ. The functioning of marine ecosystems: a fisheries perspective. In: Sinclair M, Valdimarsson, G, editors. Responsible Fisheries in the marine ecosystem. Wallingford: CAB International; 2003. p.103-23.

- Fuiman LA, Werner RG. Special considerations of fish eggs and larvae. In: Fuiman LA, Wegner RG, editors. Fishery science: the unique contributions of early life stages. New York: Blackwell Science; 2012. p.1-32.

- Garcia-Arteaga JP, Reshetnikov YS. Age and growth of the bar jack, Caranx ruber off the coast of Cuba. Vopr Ikhtiol. 1986; 25(5):120-31.

- González-Castro M, Díaz de Astarloa JM, Cousseau MB, Figueroa DE, Delpiani SM, Bruno DO, Guzonni JM, Blasina GE, Deli Antoni MY. Fish composition in a south-western Atlantic temperate coastal lagoon: spatial-temporal variation and relationships with environmental variables. J Mar Biol Assoc UK. 2009; 89(3):593-604. https://doi.org/10.1017/ S0025315409003002 
- González-Castro M, Macchi GJ, Cousseau MB. Studies on reproduction of the mullet Mugil platanus Günther, 1880 (Actinopterygii, Mugilidae) from the Mar Chiquita coastal lagoon, Argentina: similarities and differences with related species. Ital J Zool. 2011; 78(3):343-53. https://doi.org/10.1080/11250003.2010.54 9154

- Hunter JR, Lo NC, Leong RJ. Batch Fecundity in Multiple Spawning Fishes. In: Lasker R., editor. An egg production method for estimating spawning biomass of pelagic fish: application to the northern anchovy (Engraulis mordax). U.S. Department of Commerce; National Oceanic and atmospheric administration; National Marine Fisheries Service; 1985. p.67-77. (NOAA Technical Report NMFS; 36).

- Lagos AN. Características de la pesca artesanal en el Partido de la Costa (Cabo San Antonio) y perfil socioeconómico de la actividad. [Thesis]. Mar del Plata: Facultad de Ciencias Exactas y Naturales, Universidad Nacional de Mar del Plata; 2001.

- López S, Mabragaña E, Díaz de Astarloa JM, González-Castro M. Reproductive studies of Anchoa marinii Hildebrand, 1943 (Actinopterygii: Engraulidae) in the nearby-coastal area of Mar Chiquita coastal lagoon, Buenos Aires, Argentina. Neotrop Ichthyol. 2013; 13(1):221-28. https://doi.org/10.1590/1982-0224-20140083

- Macchi GJ, Acha EM. Aspectos reproductivos de las principales especies de peces en la Zona Común de Pesca Argentino-Uruguaya y en El Rincón. Noviembre, 1994. INIDEP Inf Tec. 1998; 21:67-89.

- McBride R, Stengard F, Mahmoudi B. Maturation and diel reproductive periodicity of round scad (Carangidae: Decapterus punctatus). Mar Biol. 2002; 140(4):713-22. https://doi.org/10.1007/ s00227-001-0759-4

- Navarro G, Rozycki V, Monsalvo M. Estadísticas de la Pesca Marina en Argentina: Evolución de los desembarques 2012-2016. Buenos Aires: Ministerio de Agricultura, Ganadería y Pesca; Secretaría de Agricultura, Ganadería y Pesca; 2019. Available from: https://www.magyp. gob.ar/sitio/areas/pesca_maritima/ desembarques/evolucion/Evolucion desembarques_2012_2016.pdf
- Nelson JS, Grande TC, Wilson MV. Fishes of the World. New York: Wiley; 2016.

- Pájaro M, Macchi GJ, Sánchez RP. Fecundidad y frecuencia reproductiva de las poblaciones bonaerense y patagónica de la anchoíta argentina (Engraulis anchoita). Rev Invest Desarr Pesq. 1997; (11):19-38.

- Perrotta RG, Guerrero RA, Carozza CR, Quiroga P, Macchi GJ. Distribución y estructura de tallas de la palometa (Parona signata, Carangidae) y el pampanito (Stromateus brasiliensis, Stromateidae) en relación con las condiciones oceanográficas en la Zona Común de Pesca $\left(34^{\circ} \mathrm{S}-38^{\circ} \mathrm{S}\right)$ y estimación de la longitud de primera madurez sexual. Julio de 2001. INIDEP Inf Tec. 2006; 57:1-15.

- Radonic M. Diversidad, abundancia y aspectos tróficos de la fauna ictícola acompañante de la captura del camarón y langostino, frente a las costas de Mar del Plata. [Thesis]. Mar del Plata: Facultad de Ciencias Exactas y Naturales, Universidad Nacional de Mar del Plata; 1997.

- Rodrigues AK, Macchi GJ, Acha EM, Militelli MI. Spawning and fecundity of Jenyns's sprat, Ramnogaster arcuata, a winter spawner in the temperate waters of the Río de la Plata estuary, ArgentinaUruguay. J Mar Biol Assoc UK. 2008; 88(2):423-29. https://doi.org/10.1017/ S002531540800057X

- San Roman NA. Crecimiento de la "palometa» Parona signata (Jenyns, 1842) Berg, 1895 (Pisces, Carangidae). Physis. 1976; 35(90):93-100.

- Sharpe DMT, Hendry AP. Life history change in commercially exploited fish stocks: an analysis of trends across studies. Evol Appl. 2009; 2(3):260-75. https://doi. org/10.1111/j.1752-4571.2009.00080.x

- Thulasitha WS, Sivashanthini K. Reproductive characteristics of Doublespotted queenfish, Scomberoides lysan (Actinopterygii: Perciformes: Carangidae), from Sri Lankan waters: implications for fisheries management. Acta Ichthyol Piscat. 2013; 43(1):7-13. https://doi.org/10.3750/ AIP2013.43.1.02 


\section{AUTHOR'S CONTRIBUTION @}

Santiago Julián Bianchi: Conceptualization, Data curation, Formal analysis, Funding acquisition, Investigation, Methodology, Resources, Software, Supervision, Validation, Visualization, Writing-original draft, Writing-review \& editing.

Mariano González-Castro: Conceptualization, Formal analysis, Funding acquisition, Investigation, Methodology, Project administration, Resources, Software, Supervision, Validation, Visualization, Writingoriginal draft, Writing-review \& editing.

\section{Neotropical Ichthyology}

\section{(c) (1)}

This is an open access article under the terms of the Creative Commons Attribution License, which permits use, distribution and reproduction in any medium, provided the original work is properly cited.

Distributed under

Creative Commons CC-BY 4.0

๑) 2020 The Authors.

Diversity and Distributions Published by SB

O) Official Journal of the

\section{ETHICAL STATEMENT}

Not applicable.

\section{COMPETING INTERESTS}

The authors declare no competing interests.

\section{HOW TO CITE THIS ARTICLE}

- Bianchi SJ, González-Castro M. Reproductive biology of Parona signata (Actinopterygii: Carangidae), a valuable economic resource, in the coastal area of Mar del Plata, Buenos Aires, Argentina. Neotrop Ichthyol. 2020; 18(3):e190133. https://doi.org/10.1590/1982-02242019-0133 